\title{
Persistent back pain due to malignant lymphadenopathy
}

\author{
PENELLA J WOLL AND ELAINE M RANKIN* \\ From the Department of Clinical Oncology, Guy's Hospital, London
}

SUMMARY Back pain is a common problem in rheumatology clinics and has a wide differential diagnosis. Ten young patients are described with the syndrome of persistent back pain, severe enough to prevent sleep, and characteristically eased by sitting forwards, which accompanies malignant retroperitoneal lymphadenopathy. Spinal movements and $x$ rays are typically normal. Repeated thorough examinations are required to detect superficial adenopathy or testicular swellings. Ultrasound scanning usually reveals the nodes, which can also be demonstrated by computed tomographic (CT) scanning. These young patients have a variety of cancers, many of which can be cured, so increased awareness of this syndrome could save lives.

Backache is a common problem: the general practitioner with an average list of 2500 patients can expect to see 50 cases each year, ${ }^{1}$ and many of these will later be seen in a rheumatology or orthopaedic clinic. Although most patients can be assessed in the clinic and will respond within two months to simple conservative treatment, ${ }^{2}$ severe, persistent back pain demands further investigation. Malignant causes are rare, but their early diagnosis is essential, particularly in young people who may have potentially curable cancers. We describe 10 such cases (eight seen in one year), in whom the characteristic syndrome of pain due to malignant retroperitoneal lymphadenopathy was initially overlooked.

\section{Case reports}

Table 1 gives details of all 10 cases. Three are further described below.

\section{A S E 1}

A 44 year old woman (patient No 1) who worked as a hospital cleaner, when referred to the medical oncology department described a 10 month history of severe, intermittent back pain, gradually worsening. It frequently awoke her from sleep and was only partially relieved by aspirin or ibuprofen. It was

Accepted for publication 7 April 1987.

Correspondence to Dr Penella J Woll, Growth Regulation Laboratory, Imperial Cancer Research Fund, PO Box 123, Lincoln's Inn Fields, London WC2A 3PX.

*Present address: Department of Medical Oncology, University of Glasgow, 1 Horselethill Road, Glasgow G12 9LX. initially thought to be 'menopausal'. Three months before referral an intravenous urogram was arranged by her general practitioner, but no abnormalities were seen. She had increasing lethargy and drenching night sweats for two months before referral. She noticed swellings in the neck and groins, and lymph node biopsy showed nodular sclerosing/mixed cellularity Hodgkin's disease. Chest $x$ ray showed right paratracheal and hilar lymphadenopathy. A CT scan showed splenic enlargement and retroperitoneal lymphadenopathy extending from the diaphragm to the aortic bifurcation. Her backache and other symptoms resolved after the first course of chemotherapy. Recurrent pain indicated relapse, but she has been pain free since resuming alternative chemotherapy.

CASE 2

A 34 year old foundry worker (patient No 2) had an eight month history of severe, low back pain at referral. An intravenous urogram had shown no renal pathology, and he was treated with simple analgesics without relief. The pain persisted, radiating from the low back to the left groin. Plain $x$ rays of the lumbar spine were normal, and physiotherapy was recommended by a surgeon for 'muscular' pain. The patient finally noticed swellings in the left neck and axilla. Biopsy demonstrated malignant teratoma. The testes were normal on palpation and ultrasound scan. A CT scan showed massive paraaortic, retrocrural and mediastinal lymphadenopathy. He made an initial excellent response to chemotherapy but subsequently relapsed and continues to receive treatment. 
Table 1 Details of 10 patients with severe, persistent back pain

\begin{tabular}{|c|c|c|c|c|c|c|c|}
\hline $\begin{array}{l}\text { Patient } \\
\text { No }\end{array}$ & Sex & Age & Occupation & $\begin{array}{l}\text { Duration of } \\
\text { back pain } \\
\text { to diagnosis }\end{array}$ & $\begin{array}{l}\text { Additional features } \\
\text { (and duration) }\end{array}$ & $C T$ findings & Diagnosis \\
\hline 1 & $\mathrm{~F}$ & 44 & Cleaner & 10 months & $\begin{array}{l}\text { Lymphadenopathy, } \\
\text { night sweats } \\
\text { ( } 2 \text { months })\end{array}$ & $\begin{array}{l}\text { Para-aortic } \\
\text { lymphadenopathy }\end{array}$ & $\begin{array}{l}\text { Hodgkin's } \\
\text { disease }\end{array}$ \\
\hline 2 & M & 34 & $\begin{array}{l}\text { Foundry } \\
\text { worker }\end{array}$ & 8 months & $\begin{array}{l}\text { Cervical adenopathy } \\
\text { ( } 2 \text { months })\end{array}$ & $\begin{array}{l}\text { Massive retroperitoneal } \\
\text { lymphadenopathy }\end{array}$ & $\begin{array}{l}\text { Testicular } \\
\text { teratoma }\end{array}$ \\
\hline 3 & $\mathbf{F}$ & 32 & Secretary & 11 months & $\begin{array}{l}\text { Intermenstrual blecding. } \\
\text { dyspareunia } \\
\text { (2 months) }\end{array}$ & $\begin{array}{l}\text { Numerous small para- } \\
\text { aortic nodes. } \\
\text { bulky uterus + left ovary }\end{array}$ & $\begin{array}{l}\text { Carcinoma } \\
\text { of cervix }\end{array}$ \\
\hline 4 & $\mathbf{M}$ & 37 & Van driver & 12 months & $\begin{array}{l}\text { Left sided abdominal mass } \\
\text { (1 month) }\end{array}$ & Left para-aortic mass & $\begin{array}{l}\text { Testicular } \\
\text { teratoma }\end{array}$ \\
\hline 5 & $\mathbf{M}$ & 35 & Van driver & 7 weeks & $\begin{array}{l}\text { Testicular mass } \\
(18 \text { months })\end{array}$ & $\begin{array}{l}\text { Para-aortic } \\
\text { lymphadenopathy } \\
\text { (on ultrasound and } \\
\text { lymphangiography) }\end{array}$ & $\begin{array}{l}\text { Testicular } \\
\text { teratoma }\end{array}$ \\
\hline 6 & $\mathbf{M}$ & 20 & Welder & 5 months & $\begin{array}{l}\text { Cervical adenopathy } \\
\text { ( } 3 \text { months })\end{array}$ & $\begin{array}{l}\text { Extensive retroperitoneal } \\
\text { adenopathy }\end{array}$ & $\begin{array}{l}\text { Hodgkin's } \\
\text { disease }\end{array}$ \\
\hline 7 & $\mathbf{M}$ & 28 & Clerk & 6 months & $\begin{array}{l}\text { Acute retention of urine } \\
\text { and } \text { IVC }^{*} \text { obstruction }\end{array}$ & $\begin{array}{l}\text { Massive retrocrural } \\
\text { and para-aortic } \\
\text { lymphadenopathy }\end{array}$ & $\begin{array}{l}\text { Testicular } \\
\text { teratoma }\end{array}$ \\
\hline 8 & $F$ & 38 & Unemployed & 8 months & $\begin{array}{l}\text { Hysterectomy for cervical } \\
\text { cancer } 10 \text { years ago. } \\
\text { right groin node } \\
\text { (1 month) }\end{array}$ & $\begin{array}{l}\text { Retroperitoneal } \\
\text { lymphadenopathy } \\
\text { and sigmoid colon mass }\end{array}$ & $\begin{array}{l}\text { Recurrent } \\
\text { carcinoma o } \\
\text { cervix }\end{array}$ \\
\hline 9 & $\mathbf{M}$ & 29 & Plumber & 4 months & $\begin{array}{l}\text { Swollen testis } \\
(2 \text { months })\end{array}$ & Left retroperitoneal mass & $\begin{array}{l}\text { Testicular } \\
\text { teratoma } \Omega\end{array}$ \\
\hline 10 & $\mathbf{M}$ & 29 & $\begin{array}{l}\text { Telephone } \\
\text { engineer }\end{array}$ & 3 years & $\begin{array}{l}\text { Abdominal mass } \\
\text { (2 months })\end{array}$ & $\begin{array}{l}\text { Extensive para-aortic } \\
\text { lymphadenopathy }\end{array}$ & $\begin{array}{c}\text { Testicular } \frac{0}{0} \\
\text { seminom }\end{array}$ \\
\hline
\end{tabular}

${ }^{*} \mathrm{IVC}=$ inferior vena cava.

CASE 3

A 32 year old secretary (patient No 3) complained of the sudden onset of low back pain radiating to the left buttock, thigh, and calf 11 months before referral. She was treated with traction without benefit. The pain was unrelated to position or activity, but was partially relieved by paracetamol. She sought help from an osteopath and gained some relief for three months, when the pain intensified. Aching suprapubic discomfort also developed, but an intravenous urogram was normal. Six months before referral to the medical oncology department she was reviewed by an orthopaedic surgeon. Slight narrowing of the L4-5 disc space was noted, so physiotherapy and traction were again recommended. Four months later, still in constant pain, she complained of intermenstrual bleeding and dyspareunia. Investigations showed stage IIIB carcinoma of the cervix with a bulky uterus, left ovarian mass, and numerous retroperitoneal lymph nodes. She was treated with radiotherapy, and the pain resolved. Six months later her back pain returned and investigation disclosed massive retroperitoneal lymphadenopathy with bilateral hydronephroses.
Her symptoms and lymph nodes responded promptly to chemotherapy.

\section{Discussion}

The differential diagnosis of back pain is wide, buญ malignancy is not always 'readily recognised'. ${ }^{3}$ Eaclo of the patients we describe suffered severe pain often interfering with sleep, for many months, but? cancer was not suspected. Some of them had heaves manual jobs and were at first thought to haves occupational musculoskeletal problems. Several of the patients commented that lying flat was unbear $\frac{7}{0}$ able, and the pain was typically relieved by sitting forwards. By the time the diagnosis was made most of the patients could only snatch some sleepd hunched over a table. Their family doctors sough/ help from rheumatologists, general and orthopaedic surgeons, urologists, gynaecologists, and generał physicians. They were investigated with plain $x$ rays bone scans, intravenous urography, and bariun enemata. Retroperitoneal nodes were finally de:monstrated by ultrasound, CT scanning, or lym phangiography. In each case pain relief was rapidl 
obtained after starting specific anticancer treatment. In these patients and others, back pain has been an extremely useful clinical marker of response to treatment, and may be the first indicator of relapse. ${ }^{4}$

Malignancy is an unusual cause of back pain in young people, but $5.6 \%$ of children with leukaemia present with back pain, ${ }^{5}$ and it has recently been described as a presenting symptom in young men with testicular germ cell tumours.' In older people, bony metastases frequently present with back pain, but even in the elderly, extraosseous malignancy should be considered. A recent survey of epidural cord compression associated with genitourinary neoplasms showed that $0.5 \%$ of patients with carcinoma of the prostate present with acute back pain due to metastases in the epidural space. ${ }^{7}$ Normal radiographic appearances do not exclude malignancy.

Although one in five deaths is due to cancer, the average general practitioner sees only five malignancies a year, ${ }^{\prime}$ so the hospital specialist must be especially alert to this possibility. Cancers in young people (lymphomas and testicular tumours in particular) can often be cured if diagnosed early, so vigilance and a high index of suspicion are essential. Young patients with severe, persistent back pain, typically relieved by sitting forwards, and no history of trauma, may have malignant retroperitoneal lymphadenopathy. Direct questioning may elicit a history of systemic symptoms such as night sweats or weight loss. There is no local tenderness and spinal movements are full. These patients should be repeatedly and meticulously examined so that testicular swellings, gynaecological abnormalities, and lymphadenopathy are not overlooked. Blood count and biochemical profile are usually normal, but a raised erythrocyte sedimentation rate may be mistakenly attributed to spondylitis. Plain spinal $x$ rays are typically normal. Abdominal ultrasound scanning is a useful investigation in these cases, ${ }^{4}$ and if the patient is systemically unwell retroperitoneal lymphadenopathy should be sought by CT scanning.

We are grateful to $\operatorname{Dr} P$ G Harper and the late Professor H J Rogers for permission to report their patients.

\section{References}

1 Fry J. Trends in general practice. London: Royal College of General Practitioners. 1979.

2 Edgar M A. Backache. Br J Hosp Med 1984; 32: 290-301.

3 Jayson M I V. Difficult diagnoses in back pain. Br Med J 1984; 288: $740-1$.

4 Smith D. Johnson R. James R D. Thatcher N. Upper abdominal lymphadenopathy as first presentation of relapse, identified by ultrasonography. in patients treated for small cell (oat cell) bronchogenic carcinoma. Br J Dis Chest 1985; 79: 141-6.

5 Rogalsky R J. Black G B. Reed M H. Orthopacdic manifestations of leukemia in children. J Bone Joint Surg [Am/ 1986; 68A: $494-501$.

6 Cantwell B M J, Mannix K A. Harris A L. Back pain-a presentation of metastatic testicular germ cell tumours. Lancet 1987; i: $262-4$.

7 Liskow A. Chang C H. DeSanctis P. Bensom M. Fetell M, Honsepian E. Epidural cord compression in association with genitourinary neoplasms. Cancer 1986; 58: 949-54. 